OPEN ACCESS

Edited by:

MarÃ-a Teresa MartÃ-n-Aragoneses,

National University of Distance Education (UNED), Spain

Reviewed by:

Linda Baker,

University of Maryland, Baltimore County, United States

Carlos Santoyo,

National Autonomous University of

Mexico, Mexico

*Correspondence:

Sheila L. Macrine

smacrine@umassd.edu

${ }^{+}$These authors have contributed equally to this work

Specialty section: This article was submitted to Educational Psychology, a section of the journal

Frontiers in Education

Received: 20 May 2021 Accepted: 18 August 2021 Published: 02 December 2021

Citation:

Macrine SL and Fugate JMB (2021)

Translating Embodied Cognition for

Embodied Learning in the Classroom.

Front. Educ. 6:712626.

doi: 10.3389/feduc.2021.712626

\section{Translating Embodied Cognition for Embodied Learning in the Classroom}

\author{
Sheila L. Macrine ${ }^{1 \dagger *}$ and Jennifer M. B. Fugate ${ }^{2 \dagger}$ \\ ${ }^{1}$ Department of STEM Education and Teacher Development, University of Massachusetts Dartmouth, Dartmouth, MA, \\ United States, ${ }^{2}$ Department of Psychology, College of Arts and Sciences, University of Massachusetts Dartmouth, Dartmouth, \\ MA, United States
}

In this perspective piece, we briefly review embodied cognition and embodied learning. We then present a translational research model based on this research to inform teachers, educational psychologists, and practitioners on the benefits of embodied cognition and embodied learning for classroom applications. While many teachers already employ the body in teaching, especially in early schooling, many teachers' understandings of the science and benefits of sensorimotor engagement or embodied cognition across grades levels and the content areas is little understood. Here, we outline seven goals in our model and four major "action" steps. To address steps 1 and 2 , we recap previously published reviews of the experimental evidence of embodied cognition (and embodied learning) research across multiple learning fields, with a focus on how both simple embodied learning activities - as well as those based on more sophisticated technologies of AR, VR, and mixed reality-are being vetted in the classroom. Step 3 of our model outlines how researchers, teachers, policy makers, and designers can work together to help translate this knowledge in support of these goals. In the final step (step 4), we extract generalized, practical embodied learning principles, which can be easily adopted by teachers in the classroom without extensive training. We end with a call for educators and policy makers to use these principles to identify learning objectives and outcomes, as well as track outcomes to assess whether program objectives and competency requirements are met.

Keywords: translational science, embodied cognition, teaching-learning, pedagogy, learning sciences

\section{MINDING THE (BRAIN) GAP}

Currently, there is paradox in education: a focus on evidence-based research but an abandonment of the theories (Matsushita, 2017). For example, effective performance in clinical settings requires the integration between theory and practice. Yet there is a gap between theoretical knowledge as taught in the classroom and what K-12 students experience and learn (Hashemiparast et al., 2019). Furthermore, teachers' action-based classroom research, while often promoting student achievement, is often absent of robust links to theory and is liable to neglect the application of a deductive, empirical framework. One reason for this dearth of informed practice is a lack of a framework for translating theory to practice, and in this instance, linking embodied cognition and embodied learning to effective teaching.

To promote informed research-based decisions in education, the No Child Left Behind Act (2002) mandated "scientifically based" research, which was replaced by Every Student Succeeds Act (2015) calling for "evidence-based" interventions. Still, few educators are privy to the research advances in the science of learning (Weinstein et al., 2018). Further, the limited awareness of recent theoretical and empirical evidence in cognitive science constrains the dissemination and adoption of 
research findings. There is a need for collaborative models that emphasize a bidirectional flow from researchers to practitioners (Nutley et al., 2009). Indeed, McKenney (2018) notes: “Although many studies in the learning sciences describe potential implications of policy or practice, few elaborate on how recommendations can be implemented" (p. 1).

Specifically, as Wilcox et al. (2021) point out there continues to be a significant "research to practice gap". For example, Roediger (2013) writes:

We cannot point to a well-developed translational educational science in which research about learning and memory, thinking and reasoning, and related topics is moved from the lab into controlled field trials (like clinical trials in medicine) and the tested techniques ... are introduced into broad educational practice. We are just not there yet... (p. 1).

Furthermore, one of the nation's foremost education researchers and policy analysts, Linda Darling-Hammond, argues that the rapid pace of our knowledge of human development and learning has impacted the emerging consensus about the science of learning and increased our opportunities to shape more effective educational practices (Darling-Hammond et al., 2020). Yet, she adds, to take advantage of these advances requires integrating insights across multiple fields and connecting them to our knowledge of successful approaches.

In this perspective piece, we adapted a translational research model for the learning sciences to inform teachers, educational psychologists, and practitioners on benefits of Embodied Cognition (EC) and Embodied Learning (EL) applications for the classroom.

\section{TRANSLATIONAL SCIENCE: THE NEED FOR A BRIDGE}

Translational science research emphasizes a need for appropriate professional development that fosters interdisciplinary approaches (Gilliland et al., 2017) for quickly turning biomedical findings from the laboratory, clinic, and community into interventions to improve the health of individuals and the public (NCATS-NIH, 2020). That said, to meet the challenges of collecting and disseminating the latest cognitive-science empirical research on learning, we adapted a model of translational science (Rubio et al., 2010). We call our model the Translational Learning Sciences Research for Embodied Cognition and Embodied Learning ${ }^{1}$. Our model leverages the empirical findings on EC from psychology and learning theory to provide an overarching theory for why embodied-based learning works. The call for translational research for the benefit of education is not new, although the term translational has only recently been applied in fields other

${ }^{1}$ Steps adapted from the National Institutes of Health NCATS (2020) and Rubio et al. (2010). than the natural sciences ${ }^{2}$. Here, we provide a framework for why these examples work and what generalized learning principles can be derived from these examples to impart educators with useful practice. Our model curates EC research across multiple learning fields (e.g., STEM, reading/language, social-emotional learning) while focusing on how researchers are beginning to implement both low-stakes embodied learning activities in the classroom and also those based on sophisticated technologies of AR, VR, and mixed reality (step 1 and 2 of our model). Our model then extracts generalized EL principles that can be easily used in the classroom as a starting point for researchers, teachers, policy makers, and designers to work together (step 3) to help translate and disseminate the latest research and create validated learning platforms and activities based on EC principles (step 4). The goal is to accelerate the process of transforming laboratory discoveries into new pedagogical approaches to improve learning outcomes. Before we discuss the details of our model, however, we present a quick history of $\mathrm{EC}$ and $\mathrm{EL}$ and why it matters to education.

\section{Rethinking Thinking}

Over the last forty years there has been a paradigm shift in Psychology, in which human thinking is now viewed as inseparably linked with the body and the environment (e.g., Varela et al., 1991; Wilson, 2002; Abrahamson, 2004; Hutto, 2007; Chemero, 2009; Fugate et al., 2018). Embodied views of thinking suggest that it is deeply dependent on features of the physical body of the learner, where the body plays a significant causal or constitutive role in cognitive processing (Kumar, et al., 2018; Wilson and Foglia, 2011). Such embodied views of cognition are based on bodily and neural processes of perception, action, and emotion (e.g., Hauk et al., 2004; James, 2010; Vinci-Booher and James, 2020, to name a few). For example, research also shows that simply observing another's gestures and movements can activate the mirror neuron system in the learner's brain to aid in learning through imitation (Rizzolatti et al., 1996). This finding has led to the suggestion that the mirror neuron system may be the mechanism for imitative EC (Rizzolatti et al., 1996; Iacoboni et al., 2005; Iacoboni, 2009).

We owe a great deal to developmental psychologists whose theoretical insights are affirmed by the latest neuroscientific evidence (e.g., Piaget and Cook, 1952; Piaget, 1968; Montessori, 1969; Vygotsky, 1978; Kolb, 1984; Dewey, 1989; Rogoff, 1990). Indeed, Vygotsky (1926/1997) wrote: "Thought is action ... your capacity to enact the concept as perceptuomotor activity" (pp. 161-163). Philosophically, Merleau-Ponty (1962) posited that people perceive the world first and foremost through their bodies, a type of inter-corporeality which he referred to as "enfleshment."

Although there are many theories of $\mathrm{EC}$, all are united in their emphasis on the body and draw upon two common themes. First, the body and the world (environment) are integral to forming, integrating, and retrieving knowledge. To that end, knowledge is grounded or situated in the interactions between the individual and the environment. Grounding might occur when words or linguistic

${ }^{2}$ For example, in 2015 APA launched a new journal called Translational Issues in Psychological Science. In 2015, Kaslow identified "Translating Psychological Science for the Public" as one of her APA presidential initiatives, and appointed a task force to develop new strategies to communicate psychology to the public, with the idea that psychology can one day resemble the public's knowledge of-and demand for-medical information. 
metaphors bind together individual, heterogenous instances underlying abstract concepts (Lakoff and Johnson, 1980; Mazzuca and Borghi, $2019)^{3}$. Second, knowledge is simulated: Thinking, or the use of knowledge, is re-experiencing the bodily states that were activated at the initial time of encoding, as experienced by a person's individualized interactions with the world (Barsalou, 1999; Barsalou, 2008; Gallese, 2009).

Recently, EC has expanded its reach into " $4 \mathrm{E}$ cognition", which suggests people's cognitive activity is not only embodied, but also "extended, enacted, and embedded" in the perceptual and interactive richness of their environment (see Gallagher in Rowlands, 2010). Abrahamson et al. (2021) advanced Enactivism (Varela et al., 1991) as a philosophical framework that captures "thinking as situated doing" for classroom learning. The emphasis is placed on students' experience as their source knowledge rather than on the teacher transmitting content (Petitmengin, 2007). For example, a learner and their surrounding environment constitute a system, in which the learner's thoughts, actions, and metacognitive awareness/ verbalizations (Flavell, 1979; Bernstein, 1996) may promote the discovery of new relations between their body and environment (Suwa, 2006).

\section{BOTH TEACHING AND LEARNING NEED TO BE RE-EXAMINED}

Our current educational delivery systems (i.e., teacher education, pedagogy, curriculum) and approaches can be traced back to "disembodied" views of human thinking. Specifically, much of teaching pedagogy/curriculum continue to view learning as abstracted and separate from the body (Macrine, 2002) and fails to understand the latest psychological and neuroscientific evidence from EC. Similarly, teacher training/pedagogy, while emphasizing constructivist's approaches, tends to devolve-in-practice to positivist's skills in preparation for standardized tests (Klein et al., 2019). According to Nathan (2012), teaching continues to focus on foundational knowledge or "formalism first". Specifically, formalism first "incorrectly advocates the teaching/mastery of formalisms often considered prerequisite to applied knowledge" [that] "privileges formal, scientific knowledge over applied knowledge" (Nathan, 2012, p.126). Further, Nathan asserts that formalisms only gain their meaning with embodied experiences through real-world interaction and therefore the experiences are what ground formalisms, not the other way around. Similarly, Wertsch (1985) noted that a construct is shared when the action and affordances are experienced with the adult and contextualized in the real world.

\section{Rethinking Learning}

Derived from EC principles, EL constitutes a contemporary pedagogical theory that emphasizes the use of the body in educational practice, as well as student-teacher interaction both in and outside the classroom (Smyrnaiou and Sotiriou, 2016; Kosmas and Zaphiris, 2018; Georgiou

${ }^{3}$ Other theories suggest that there is no grounding necessary because there are no mental representations (Gallagher, 2005; Hutto, 2005; Thompson, 2007; Chemero, 2009; Hutto and Myin, 2012; Hutto and Myin, 2017). and Ioannou, 2019). EL posits that a person's own actions (and the observation of others' actions) interact with environmental affordances, and together scaffold the process of learning.

While EC uses similar approaches to active learning, EL includes a variety of body-based techniques (i.e., gestures, imitations, simulations, sketching, and analogical mapping) (Alibali and Nathan, 2007; Weisberg and Newcombe, 2017) that hold promise for understanding the role of action and experience in early development, as well as to scaffold learning in more formal educational settings (Kontra et al., 2012). Following suit, embodied design is a pedagogical framework that "seeks to promote grounded learning by creating situations in which students can be guided to negotiate tacit and cultural perspectives on phenomena under inquiry" (Abrahamson, 2013, p. 224).

\section{OUR MODEL: TRANSLATIONAL LEARNING SCIENCES RESEARCH FOR EMBODIED COGNITION AND EMBODIED LEARNING}

In light of recent empirical demonstrations of how EC/EL works, our model of Translation Learning Sciences Research for Embodied Cognition and Embodied Learning has seven goals: 1) making sense of and disseminating clinical and empirical research findings; 2) closing the gap between research and application; 3) combining cognitive science and pedagogy to share pertinent information; 4) improving teaching and learning through embodied applications; 5) confirming or debunking current trends, (i.e., neuromyths); 6) elucidating conceptual frameworks for sensorimotor and body-based learning; and 7) recommending curriculum, designs, taxonomies, technology, and development to inform policy.

From these goals, we outline the following four action steps: 1) Promote the multidirectional and multidisciplinary integration of basic embodied research to elucidate or to debunk current trends in teaching and learning; 2) Compile the embodied research to be analyzed, translated, and make connections to improve pedagogical approaches, with the long-term aim of improving teaching and learning; 3) Develop and disseminate resources and tools to help individuals at all levels of expertise develop a better understanding of EL; 4) Focus on the creation of appropriate embodied curriculum and the development of taxonomies to identify objectives, and track outcomes that will assess whether program objectives and competency requirements are being met. We believe that our model can serve as an expeditious way to systematically collate, translate, and disseminate the latest embodied research geared towards improved learning outcomes. In other words, this is where science meets the real world of schooling.

In a larger research project, we have addressed steps 1 and 2 by carefully curating examples from leading experts to show how EC can be integrated into classroom practice (Macrine and Fugate, 2020). Such research examples are based on behavioral and neuroimaging experimentation in the fields of language and reading comprehension, STEM, and social-emotional knowledge. By way of a few noteworthy examples, Kiefer et al. 
(2015) found that young students who relied on physically writing (compared to typing) had improved word reading and word writing. James (2010) found that four-to-five year-old participants, who had practiced writing letters through handwriting (but not other ways), showed adult-like brain activation when subsequently viewing letters. Further, college students demonstrated better recall of handwritten notes vs. typed notes (Mangen et al., 2015). In addition, Glenberg and colleagues (Glenberg and Kaschak, 2002; Glenberg et al., 2008; Glenberg and Gallese, 2012) showed how vocabulary acquisition can be enhanced by shared communication and physical pantomime, both which allow for the grounding of information to concrete objects. In another example, Boaler and colleagues (Boaler et al., 2016) demonstrated how finger perception predicted learning math all the way through college, and that young children with good finger-based numerical representations showed better arithmetic skills. In addition, the panoply of motion-based technologies and interactiveuser gaming platforms have allowed VR and AR designers to create technology-enabled EL experiences. Such technologies range from gesture-based to full-body interactive technologies, with the latter making up fewer options and focusing mainly on VR and AR technologies (Trninic and Abrahamson, 2012; Johnson-Glenberg, 2018; Georgiou and Ioannou, 2019).

Several of these researchers, and numerous others working within the field of learning design and practice, have turned such research findings into EL technologies for the classroom. As an example, the Moved by Reading approach uses simulation or "acting-out" in two stages to enhance reading (Glenberg et al., 2004). In the first stage, called physical manipulation, children manipulate toys to simulate the story that they are reading. The second stage is called imagined manipulation, where children are taught how to mentally simulate or imagine doing the actions. The authors found that physical and imagined manipulations contributed to larger gains in memory and comprehension than dis-embodied reading approaches. Gomez and Glenberg (2022) demonstrated the importance of pantomiming while reading new physics content. Abrahamson and colleagues designed multiple, successful embodied instruction design applications, called Mathematical Imagery Trainers (MITs). In one high technology-based project known as the Kinemathics project (Abrahamson et al., 2011), students move their arms in proportional distances to measurements of similar magnitude displayed on a screen. Using a trial-and-error approach, correct answers turn the screen green and incorrect ones turn it red, which reinforces the rules underlying the relationship (i.e., a 1:2 rule). And, in another specialized application, Abrahamson and Lindgren (2014) developed MEteor, an interactive MR simulation that uses a laser and floor-projected imagery. In this application, students use their bodies to simulate an orbit around a virtual planet to learn about formal concepts such as gravitational acceleration and mass.

Perhaps just as important is that many of these applications can be adapted to students with learning disabilities. Indeed, advances in EL have been utilized with students with ASD (De Jaegher, 2013; Eigsti, 2013; Eigsti, 2015), deaf students, and students with motor impairment (Kosmas et al., 2019; Tancredi et al., 2022).
In the remainder of this perspective, we focus on steps 3 and 4 of our model. Step 3 advocates for a coordinated effort - a type of interactive educational/cognitive-science consortium - among researchers, educational psychologists, teachers, school psychologists, policy makers, and textbook publishers to translate and disseminate/share the latest findings, applications, and implementation of the latest developments. These include bringing such issues to the attention of: 1) university-affiliated design-based research laboratories; 2) school personnel-primarily teachers but also technology experts and principals; 3) parents-as individuals and via various organized bodies-invested in school policy on infrastructure, resources, and pedagogy; 4) non-profit education-promoting groups, who are hampered neither by publication nor sales constraints; 5) commercial educational-technology companies with forwardthinking strategies; and 6) reporters, bloggers, etc. who cover the educational beat and can bring these issues to the attention of the wider public, including city, state, and federal policymakers. These many-and in rare occasions collaborations among them-could hasten the experimental application of cutting-edge research in the form of convivial instructional resources. For example, a national database of open-science materials and data could be coordinated to allow any teacher to use the materials and to contribute to "open science", which has become popular already in psychology ${ }^{4}$.

To begin to address step 4, we have extracted the following key appropriate embodied principles (Table 1) for future practitioners, researchers, and teachers to guide the researchto-practice transition.

The final step will be for educators and policy makers to use these principles to develop taxonomies of embodied curriculum, identify learning objectives and outcomes, and track outcomes to assess whether program objectives and competency requirements are met. Specifically, "in situ" assessments will be needed, as retrospective measures of learning (e.g., written tests, etc.) are at odds with the very nature of EL (Georgiou and Ioannou, 2019). As Roschelle et al. (2011) point out: "Meaningful educational change almost always involves coordinating and aligning related changes (e.g., in curriculum, technology use, pedagogy, assessment, and school leadership)" (p. 33).

\section{SUMMARY AND FUTURE DIRECTIONS}

Our Translational Learning Sciences Research for Embodied Cognition and Embodied Learning came about because there is a need for an expeditious pipeline to get the latest cognitive science and empirically validated educational applications out to the public. Our model provides a bi-directional conduit in which research findings and applications can flow quickly. We are advancing our model as a vehicle to continue to collate vetted examples of EL as they relate to EC theory. Our model is aimed at informing EL in an earnest way through a translational science approach ${ }^{5}$. We hope that it encourages

\footnotetext{
${ }^{4}$ see https://www.apa.org/science/about/psa/2019/02/open-science.

${ }^{5}$ Such a "translation" of psychology research to classroom-practice has, however, been done for research on metacognition (Flavell, 1979) (e.g. Tanner, 2012; Beach et al., 2020). Beach and colleagues have an entire manual on the role of metacognition in teaching and learning, highlighting four key findings that are similar in effect to our extracted teaching principles for embodied cognition.
} 
TABLE 1 | Key Principles for Translational Learning Sciences Research for Embodied Cognition and Embodied Learning.

\begin{tabular}{|c|c|c|c|c|}
\hline $\begin{array}{l}\text { EC principle and generalized } \\
\text { advice }\end{array}$ & Domain & Scientific findings $^{*}=$ classroom-vetted K-12 & Classroom resources/Links & Specific teaching principle \\
\hline $\begin{array}{l}\text { 1) The use of body-based learning } \\
\text { (i.e., sensorimotor learning, including } \\
\text { using whole-body and fingers, and } \\
\text { gesturing). }\end{array}$ & Reading & $\begin{array}{l}\text { Vocabulary acquisition, reading comprehension } \\
\text { skills, and cued and spontaneous recall rely on } \\
\text { connecting linguistic elements (e.g., the words and } \\
\text { phrases in the linguistic input) to sensorimotor capacity } \\
\text { (e.g., the perceptual or motor skills to which those }\end{array}$ & $\begin{array}{l}\text { Embrace and Moved by Reading programs } \\
\text { https://www.movedbyreading.com/ }\end{array}$ & $\begin{array}{l}\text { Teachers can encourage word } \\
\text { learning and language } \\
\text { comprehension through: 1) dialogic } \\
\text { reading, in which the adult asks } \\
\text { questions related to the text that are }\end{array}$ \\
\hline $\begin{array}{l}\text { Teachers should promote body- } \\
\text { based learning, including self- } \\
\text { generated actions involving touch, } \\
\text { sight, drawing, and writing. }\end{array}$ & & $\begin{array}{l}\text { linguistic elements refer) [Glenberg and Kaschak } \\
\text { (2002), Glenberg et al. (2004)*, Kaschak et al. (2005), } \\
\text { Pulvermuller (2005), Glenberg et al. (2007), Marley et al. } \\
(2007)^{\star} \text {, Glenberg (2008), Glenberg et al. (2009)*, } \\
\text { Glenberg et al. (2011)*, Zwaan (2014), Kaschak et al. } \\
(2017)^{\star} \text { ]. }\end{array}$ & & $\begin{array}{l}\text { intended to prompt dialogue; 2) } \\
\text { "acting out" vocabulary or sentences } \\
\text { through play with a physical } \\
\text { representation of content depicted in } \\
\text { the text; and 3) performing iconic } \\
\text { actions to illustrate word meaning } \\
\text { through gesture or pantomime. }\end{array}$ \\
\hline- & Reading & $\begin{array}{l}\text { Taking notes with pen and paper (vs. typing) } \\
\text { encourages summative understanding because of } \\
\text { the slowness (but also richness) of physically writing } \\
\text { [Mueller and Oppenheimer, (2014)]. }\end{array}$ & - & $\begin{array}{l}\text { For language and material } \\
\text { comprehension, teachers can } \\
\text { encourage students to handwrite } \\
\text { notes that are summative (and less } \\
\text { dictated). Students' self-generated, } \\
\text { summative arguments actions can be } \\
\text { more powerful than memorization or } \\
\text { writing notes verbatim. }\end{array}$ \\
\hline
\end{tabular}

$\begin{array}{ll}\text { Reading } & \text { Reading from print books (rather than digitally on } \\ & \text { computers or tablets) can enhance kinesthetic and } \\ & \text { tactile feedback and can improve information general } \\ & \text { comprehension. [Mangen (2008), Mangen et al. }\end{array}$

(2013)*, Delgado et al. (2018), Mangen et al. (2019)].

\begin{abstract}
Handwriting Exploring letters visual-haptically (vs. visual only) improves handwriting and is important for letter learning and early literacy [Naka (1998)*, Longcamp et al. (2003), Bara et al. (2004)*, Longcamp et al. (2005), Longcamp et al. (2008), Mangen and Velay (2010), Bara and Gentaz (2011)*, James and Engelhardt (2012), Kiefer et al. (2015)*, Mangen et al. (2015), Mangen and Balsvik (2016), James (2017)].
\end{abstract}

Math and Finger use and perception predict mathematics Science achievement [Berteletti and Booth (2015), Boaler et al. (2016)].

YouCubed Team: https://www.youcubed. org/wp-content/uploads/2017/03/FingerActivities-vF.pdf

Math and Mathematical attainment is related to interceptive Science timing ability and is learned through perceptually guided actions that instantiate the concept as a movement form [Abrahamson (2004)*, Abrahamson $(2007)^{\star}$, Gracia-Bafalluy (2008)*, Reinholz et al. (2010)*, Abrahamson et al. (2011)*, Abrahamson (2014), Abrahamson et al. (2014)*, Abrahamson and Trninic (2015)*, Giles et al. (2018), Abrahamson et al. (2020)].
3D Multiplication Table (Embodied Design Laboratory): https://edrl.berkeley.edu/design/ 3d-multiplication-table/

Math Imagery Trainers (MITs) MIT-Proportion and MIT-Parabola (Embodied Design Laboratory)

https://edrl.berkeley.edu/design/

mathematics-imagery-trainer/

Kinemathics (Embodied Design Laboratory): https://edrl.berkeley.edu/projects/ kinemathics/

Combinations Tower (Embodied Design Laboratory): https://edrl.berkeley.edu/design/ combinations-tower/

YouCubed Team: https://www.youcubed. org/tasks/

4-Blocks NetLogo (Center for Connected Learning and Computer-Based Modeling) http://ccl.northwestern.edu/netlogo/docs/ Dice Stalagmite NetLogo (Center for Connected Learning and Computer-Based
Teachers can encourage paper books or electronic reading displays (e.g. Kindle), which more closely simulate the physicality of print books, especially for longer passages.

Teachers can encourage learning to write by hand.

Teachers can encourage solving mathematical problems with realworld objects, rather than solving comparable symbolically presented problems.

Teachers can provide multidimensional experiences in mathematics, which include multiple opportunities to see and experience concepts through touch, sight, drawing, and writing in words. 
TABLE 1 | (Continued) Key Principles for Translational Learning Sciences Research for Embodied Cognition and Embodied Learning.

\begin{tabular}{|c|c|c|c|c|}
\hline $\begin{array}{l}\text { EC principle and generalized } \\
\text { advice }\end{array}$ & Domain & Scientific findings $^{*}=$ classroom-vetted K-12 & Classroom resources/Links & Specific teaching principle \\
\hline \multirow{10}{*}{ - } & & & $\begin{array}{l}\text { Modeling): https://ccl.northwestern.edu/ } \\
\text { netlogo/models/DiceStalagmite }\end{array}$ & \\
\hline & $\begin{array}{l}\text { Math and } \\
\text { Science }\end{array}$ & $\begin{array}{l}\text { Human capacity to perceive the environment in new } \\
\text { ways is predicated on learning to move in new ways } \\
\text { because perception of scientific concepts is } \\
\text { inherently for action [Mechsner et al. (2001), Alibali } \\
\text { and Nathan (2012)*, Walkington et al. (2019), Nathan } \\
\text { et al. (2020)]. }\end{array}$ & $\begin{array}{l}\text { Block Stalagmite (Embodied Design } \\
\text { Laboratory): https://edrl.berkeley.edu/design/ } \\
\text { 4-block-stalagmite/ } \\
\text { The Eye Trick (Embodied Design Laboratory): } \\
\text { https://edrl.berkeley.edu/design/the-eye- } \\
\text { trick/ }\end{array}$ & $\begin{array}{l}\text { Teachers can create conditions that } \\
\text { enact movement that captures the } \\
\text { dynamical sense of a concept. }\end{array}$ \\
\hline & & & $\begin{array}{l}\text { MEteor: Developing Physics Concepts } \\
\text { through Body-based Interaction with a Mixed } \\
\text { Reality Simulation (Lindgren et al., 2016) }\end{array}$ & \\
\hline & & & $\begin{array}{l}\text { The Hidden Village: Mathematical Reasoning } \\
\text { through Movement https://multiplex.videohall. } \\
\text { com/presentations/1662 }\end{array}$ & \\
\hline & & & $\begin{array}{l}\text { Magna-AR: https://www.vieyrasoftware.net/ } \\
\text { physics-toolbox-ar }\end{array}$ & \\
\hline & & & $\begin{array}{l}\text { PhysicsToolbox: https://play.google.com/ } \\
\text { store/apps/details?id=com.chrystianvieyra. } \\
\text { physicstoolboxsuite\&hl=en_US }\end{array}$ & \\
\hline & & & $\begin{array}{l}\text { HistoBlocks: https://ccl.northwestern.edu/ } \\
\text { netlogo/models/HistoBlocks }\end{array}$ & \\
\hline & & & $\begin{array}{l}\text { The Marbles Scooper: https://edrl.berkeley.edw/ } \\
\text { design/the-marbles-scooper/ }\end{array}$ & \\
\hline & & & $\begin{array}{l}\text { Data science K-12 initiative: https://www. } \\
\text { youcubed.org/resource/data-literacy/ }\end{array}$ & \\
\hline & & & $\begin{array}{l}\text { SMALLab Learning, LLC: https://www. } \\
\text { smallablearning.com/research } \\
\text { Ratio and Proportion (Phet Interaction } \\
\text { Simulations): https://phet.colorado.edu/en/ } \\
\text { simulation/ratio-and-proportion. }\end{array}$ & \\
\hline
\end{tabular}

Math and Gestures are spontaneous or purposeful movements Science

2) Imitative body-based learning from others, including attention to other's body movements.

Teachers need to be attentive to students' whole-body learning of the body that often accompany speech, serve as a way to convey ideas, and predict the quality of one's argument in mathematics and sciences (e.g. physics) [Kontra et al. (2015), Johnson-Glenberg et al. (2016)*, Johnson-Glenberg and Megowan-Romanowicz

(2017), Johnson-Glenberg (2018), Megowan-

Romanowicz (2022)].
SocioEmotional
Observational learning is important for acquiring and system (MNS) responds robustly to observation and imitation of face and hand actions

[lacoboni et al. (2005), Immordino-Yang and Damasio (2007), Caspers et al. (2010), Caramazza et al.

(2014), Aziz-Zadeh et al. (2018), Ferrari and Coudé communicating knowledge. The mirror neuron
Teachers can consider how gestures support understanding and revea learners' struggles and understandings.

Teachers can directly interact with learners' gestures when describing their embodied experiences with embodied learning technologies by: (1) pointing out/highlighting aspects of the gesture; and/or (2) contributing new dynamic gestural imagery to the gesture.

Teachers can attend to not only what learners say, but also to learner's movements, idiosyncratic forms of perception, and how learners interpret their embodied experiences. Noticing these behaviors can help teachers prompt perceptual-motor activity at timely moments.

Teachers can engage in demonstrating a skill, and students should engage in subsequent imitation or emulation to enhance observational learning.

(Continued on following page) 
TABLE 1 | (Continued) Key Principles for Translational Learning Sciences Research for Embodied Cognition and Embodied Learning.

EC principle and generalized $\quad$ Domain $\quad$ Scientific findings ${ }^{*}=$ classroom-vetted K-12 $\quad$ Classroom resources/Links
advice

experiences and intentionally

incorporate movement into learning

activities, which can increase the

connection between the physical

environment and academic goals

through situated learning. Teachers

should assess students' developing

understanding by attending to both

their gestures and body language.
(2018), Keysers et al. (2018), Butera and Aziz-Zadeh (2022)].
All

Socio-

Emotional

Teachers should support student engagement by monitoring what the individual is doing, encouraging them to come up with their own strategies and reflect.
Students learn through repeatedly attempting to reconstruct actions performed by others, and follow action goals of others [Flanagan and Johansson (2003), Gerofsky, (2011)*, Hall and Nemirovsky (2012), Gredebäck and Falck-Ytter (2015), Vogelstein et al. (2019)].

All

All

Special

Needs

All

4) Use of manipulatives with relevant affordances (including ARNR but also "simpler" actions)
Teacher and students who engage in joint attention experience more positive affect, likely attributable to increased agency [Steinbrenner and Watson (2015), Grynszpan et al. (2017)].
Intercorporeal attunement (i.e., responsiveness) is bidirectional, that is, students attune to teachers. In conversations, even multi-person discussions, speakers are constantly returning to each other. This is a rapid, iterative, and reciprocal process [Radford and Roth (2011), Shvarts and Abrahamson (2019)].

Responsive teaching involves: 1) drawing out, attending to, and engaging with aspects of learners ideas that have potential disciplinary value or substance; and 2) engaging in ongoing proximal formative assessment (e.g., continuously monitoring students' ideas to adapt instructional support in the moment) [Robertson et al. (2016), Flood et al. (2020), Flood et al. (2022)].

Individuals with motor and sensory impairment will have different experiences over time that shape how they come to understand the world, mandating the need for including "inclusive design" [Ma (2017), Abrahamson et al. (2019), Chen et al. (2020), Tancredi et al. (2022)].
Augmented reality (AR) technologies enhance and expand opportunities to learn through moving and can improve both visuospatial capabilities and enhanced student-reported interest leading to more
Balance Board Math (Embodied Design Laboratory/Tancredi: https://edrl.berkeley. edu/projects/balance-board-math/

Magical Musical Mat (Embodied Design Laboratory/Chen): https://edrl.berkeley.edu/ projects/magical-musical-mat/

SignEd|Math (Embodied Design Laboratory/ Krause): https://edrl.berkeley.edu/projects/ signedmath/

Titans of Space (Drash VR LLC): http://www. drashvr.com/titansofspace.html
Teachers can use goal-directed human movement to illustrate new concepts.

Teachers can use simple bodily movements to help learners understand more advanced concepts (e.g., opposing forces as argument opposition) as they develop.

Teachers can engage in joint attention with the student by encouraging collaborative situated interactions.
Teachers can create a classroom climate that encourages students to express and discuss how concepts "look," "move," "feel," etc.

Teachers can make instructiona decisions based on what they can see that was not understood.

Teachers can try to reformulate learners' ideas to help them extend and connect these ideas with new disciplinary understandings. One way to achieve this is through the practice of revoicing, (i.e., recasting learners' multimodal contributions by repeating some content) yet also reformulating (modifying the content of) and/or elaborating (adding new content to) the ideas learners have shared.
Teachers can encourage the use of concrete manipulatives (e.g., blocks, chips, Dienes blocks, Geotiles, balance scales, paper clips, popsicle (Continued on following page) 
TABLE 1 | (Continued) Key Principles for Translational Learning Sciences Research for Embodied Cognition and Embodied Learning.

\begin{tabular}{|c|c|c|c|c|}
\hline $\begin{array}{l}\text { EC principle and generalized } \\
\text { advice }\end{array}$ & Domain & Scientific findings $^{*}=$ classroom-vetted K-12 & Classroom resources/Links & Specific teaching principle \\
\hline $\begin{array}{l}\text { Teachers should root themselves in } \\
\text { practices that exemplify interaction } \\
\text { that supports conceptual modeling, } \\
\text { including digital simulations as well as } \\
\text { physical manipulatives, especially for } \\
\text { STEM fields. }\end{array}$ & & $\begin{array}{l}\text { accurate performance (vs. traditional instruction) } \\
\text { [Carbonneau et al. (2013), Lindgren and } \\
\text { Johnson-Glenberg (2013), Abrahamson and } \\
\text { Lindgren, (2014), Donovan et al. (2014), Carbonneau } \\
\text { and Marley (2015), Johnson-Glenberg et al. (2016) } \\
\text { Lindgren et al. (2016)*, Johnson-Glenberg and } \\
\text { Megowan-Romanowicz (2017), Vieyra et al. (2020), } \\
\text { Donovan and Alibali (2021), Donovan and Alibali } \\
\text { (2022), Megowan-Romanowicz (2022); Vierya and } \\
\text { Vierya (2022)*]. }\end{array}$ & $\begin{array}{l}\text { Catch a Mimic (Embodied-Games.com): } \\
\text { www.embodied-games.com }\end{array}$ & $\begin{array}{l}\text { sticks, and beanbags) and } \\
\text { computerized or AR technologies } \\
\text { created and vetted for learning. }\end{array}$ \\
\hline- & All & $\begin{array}{l}\text { All technologies have their own material affordances } \\
\text { and sensorimotor contingencies, which frame and } \\
\text { constrain a person's interaction with a device [Gibson } \\
\text { (1979), Gaver (1991), Kamii et al. (2001), Moyer } \\
\text { (2001)]. }\end{array}$ & - & $\begin{array}{l}\text { Teachers can consider the following } \\
\text { when deciding whether and how to } \\
\text { use a given manipulative: 1) } \\
\text { identifying the target concept, } \\
\text { considering how the object under } \\
\text { consideration relates to the target } \\
\text { concept; 2) considering what actions } \\
\text { the object affords; and 3) considering } \\
\text { how those actions relate to the target } \\
\text { concept. }\end{array}$ \\
\hline
\end{tabular}

\begin{tabular}{|c|c|c|c|c|}
\hline- & All & $\begin{array}{l}\text { Manipulatives are most effective when their design } \\
\text { enables students forms of sensorimotor engagement } \\
\text { that prompt diverse ways of reasoning related to the } \\
\text { content, as well as coordinating among these different } \\
\text { ways of reasoning [Abrahamson et al. (2014)]. }\end{array}$ & - & - \\
\hline $\begin{array}{l}\text { 5) Bodily-based sensory awareness of } \\
\text { internal states } \\
\text { Teachers should encourage students } \\
\text { to express pride, enjoyment, and } \\
\text { hopes about their learning, and } \\
\text { engage in positive attitudes about the } \\
\text { efficacy of body-based learning. }\end{array}$ & $\begin{array}{l}\text { Socio- } \\
\text { Emotional }\end{array}$ & $\begin{array}{l}\text { Body-based approaches and therapies which lead to } \\
\text { the disambiguation of affective states can improve } \\
\text { emotion regulation and perception of emotion, as well } \\
\text { as improve attention and performance in the } \\
\text { classroom [O'Conner et al. (2017), Jagers et al. } \\
\text { (2019)]. }\end{array}$ & CASEL: https://casel.org/resources/ & $\begin{array}{l}\text { Teachers can capitalize on teaching } \\
\text { emotion vocabulary and mindfulness to } \\
\text { individuals to not only improve emotional } \\
\text { interactions and regulation, but also to } \\
\text { improve attention, focus, and cognitive } \\
\text { awareness, which all facilitate academic } \\
\text { performance. }\end{array}$ \\
\hline- & $\begin{array}{l}\text { Socio- } \\
\text { Emotional }\end{array}$ & $\begin{array}{l}\text { Individuals higher in granularity report more flexible } \\
\text { emotional regulation abilities [Barrett et al. (2001), Boden } \\
\text { et al. (2012)], have a less reactive coping style [Tugade } \\
\text { et al. (2004)], and are less biased by incidental emotions } \\
\text { when making moral decisions [Cameron et al. (2013), } \\
\text { Fugate and Wilson-Mendenhall (2022)]. }\end{array}$ & - & $\begin{array}{l}\text { Teachers can label student's } \\
\text { emotional states and include socio- } \\
\text { emotional learning (SEL) into the } \\
\text { classroom. Emotions can be labeled } \\
\text { and incorporated into the category } \\
\text { knowledge about human behavior. }\end{array}$ \\
\hline- & $\begin{array}{l}\text { Socio- } \\
\text { Emotional }\end{array}$ & $\begin{array}{l}\text { Knowing one's own feelings may also help with } \\
\text { understanding others' feelings [Saarni (1997)]. }\end{array}$ & - & - \\
\hline- & $\begin{array}{l}\text { Socio- } \\
\text { Emotional }\end{array}$ & $\begin{array}{l}\text { The awareness practices that characterize mindfulness- } \\
\text { based interventions are thought to improve emotion } \\
\text { regulation by cultivating a more fine-grained awareness of } \\
\text { what is occurning in one's mind [Hill and Updegraff (2012), } \\
\text { Roemer et al. (2015), Carsley et al. (2018)]. }\end{array}$ & - & $\begin{array}{l}\text { Teachers can consider adding in } \\
\text { mindfulness practices into the } \\
\text { classroom. }\end{array}$ \\
\hline
\end{tabular}

cognitive science and educational researchers to offer and make their research available across the fields of educational psychology, educational policy, and teacher education to improve student outcomes and classroom pedagogy. We want to improve communication between scientists and practitioners and to avoid the occurrence of misconceptions, such as neuromyths to shape their pedagogies (Tan and Amiel, 2019). Our model was developed to reimagine how educators can access reliable research to inform their own pedagogy to create a more equitable and just schooling for all.
While we applied this new education-based translational research model to embodied cognition for teaching and learning, we believe that our model can also be used in different educational research contexts. Thus, this approach could provide a vehicle for the dissemination of theory-driven empirical findings translated into evidencebased classroom practice and enable bi-directional suggestions for future research, best practice, and theory development. Ultimately, the continued development of such pathways will lead to the advancement of-and 
efficient translation of-the latest cognitive science and educational psychology research findings for the educational community.

\section{AUTHOR CONTRIBUTIONS}

SM and JF contributed to all aspects of the article including model development and writing, as well as approved the submitted version.

\section{REFERENCES}

Abrahamson, D. (2004). "Embodied Spatial Articulation: A Gesture Perspective on Student Negotiation between Kinesthetic Schemas and Epistemic Forms in Learning Mathematics," in Proceedings of the Twenty Sixth Annual Meeting of the North American Chapter of the International Group for the Psychology of Mathematics Education. Editors D. E. McDougall and J. A. Ross (Windsor: Preney), 2, 791-797.

Abrahamson, D. (2007). "Handling Problems: Embodied Reasoning in Situated Mathematics," in Proceedings of the $29^{\text {th }}$ Annual Meeting of the North American Chapter of the International Group for the Psychology of Mathematics Education. Editors T. Lamberg and L. Wiest (Lake Tahoe: University of Nevada), 219-226.

Abrahamson, D. (2013). "Toward a Taxonomy of Design Genres: Fostering Mathematical Insight via Perception-Based and Action-Based Experiences," in Proceedings of the 12th Annual Interaction Design and Children Conference (IDC 2013). Editors J. P. Hourcade, E. A. Miller, and A. Egeland (New York, NY: The New School \& Sesame Workshop), 218-227.

Abrahamson, D. (2014). Building Educational Activities for Understanding: An Elaboration on the Embodied-Design Framework and Its Epistemic Grounds. Int. J. Child-Computer Interaction 2 (1), 1-16. doi:10.1016/j.ijcci.2014.07.002

Abrahamson, D. (2017). "Embodiment and Mathematics Learning," in The SAGE Encyclopedia of Out-Of-School Learning. Editor K. Pepper (Thousand Oaks, CA: SAGE Publications, Inc.), 1, 248-252. doi:10.4135/9781483385198.n98

Abrahamson, D. (2021). Grasp Actually: An Evolutionist Argument for Enactivist Mathematics Education. Hum. Dev. 1, 1-17. doi:10.1159/000515680

Abrahamson, D., and Lindgren, R. (2014). "Embodiment and Embodied Design," in The Cambridge Handbook of the Learning Sciences. Editor R. K. Sawyer. 2nd ed. (Cambridge, United Kingdom: Cambridge University Press), 358-376.

Abrahamson, D., and Trninic, D. (2015). Working Out: Mathematics Learning as Motor Problem Solving in Instrumented Fields of Promoted Action. In Knowing and Learning in Interaction: A Synthetic Agenda for the Learning Sciences. Editors A. A. diSessa, M. Levin, and N. J. S. Brown. New York, NY: Routledge, 212-235.

Abrahamson, D., Dutton, E., and Bakker, A. (2021). "Towards an Enactivist Mathematics Pedagogy," in The Body, Embodiment, and Education: An Interdisciplinary Approach. Editor S. A. Stolz (New York: Routledge).

Abrahamson, D., Flood, V. J., Miele, J. A., and Siu, Y.-T. (2019). Enactivism and Ethnomethodological Conversation Analysis as Tools for Expanding Universal Design for Learning: The Case of Visually Impaired Mathematics Students. ZDM Maths. Edu. 51 (2), 291-303. doi:10.1007/s11858-018-0998-1

Abrahamson, D., Gutiérrez, J., Charoenying, T., Negrete, A., and Bumbacher, E. (2012). Fostering Hooks and Shifts: Tutorial Tactics for Guided Mathematical Discovery. Tech. Know Learn. 17 (1-2), 61-86. doi:10.1007/ s10758-012-9192-7

Abrahamson, D., Lee, R. G., Negrete, A. G., and Gutiérrez, J. F. (2014). Coordinating Visualizations of Polysemous Action: Values Added for Grounding Proportion. ZDM Maths. Edu. 46 (1), 79-93. doi:10.1007/ s11858-013-0521-7

Abrahamson, D., Nathan, M. J., Williams-Pierce, C., Walkington, C., Ottmar, E. R., Soto, H., and Alibali, M. W. (2020). The Future of Embodied Design for

\section{FUNDING}

A Subvention Grant was awarded by the University of Massachusetts Dartmouth's Office of the Dean of the College of Arts \& Sciences.

\section{ACKNOWLEDGMENTS}

Special thanks to Professor Dor Abrahamson for his advise on this paper.

Mathematics Teaching and Learning. Front. Edu. (5), 147. doi:10.3389/ feduc.2020.00147

Abrahamson, D., Trninic, D., Gutiérrez, J. F., Huth, J., and Lee, R. G. (2011). Hooks and Shifts: A Dialectical Study of Mediated Discovery. Tech. Know Learn. 16 (1), 55-85. doi:10.1007/s10758-011-9177-y

Alibali, M., and Nathan, M. J. (2007). “Teachers' Gestures as a Means of Scaffolding Students' Understanding: Evidence from an Early Algebra Lesson," in Video Research in the Learning Sciences. Editors R. Goldman, R. Pea, B. Barron, and S. J. Derry (Mahwah, NJ: Lawrence Erlbaum), 349-366.

Alibali, M. W., and Nathan, M. J. (2012). Embodiment in Mathematics Teaching and Learning: Evidence from Learners' and Teachers' Gestures. J. Learn. Sci. 21 (2), 247-286. doi:10.1080/10508406.2011.611446

Alibali, M. W., Young, A. G., Crooks, N. M., Yeo, A., Wolfgram, M. S., Ledesma, I. M., Nathan, M. J., Breckinridge Church, R., and Knuth, E. J. (2013). Students Learn More when Their Teacher Has Learned to Gesture Effectively. Gest. 13 (2), 210-233. doi:10.1075/gest.13.2.05ali

Aziz-Zadeh, L., and Gamez-Djokic, V. (2016). Comment: The Interaction Between Metaphor and Emotion Processing in the Brain. Emot. Rev. 8 (3), 275-276. doi:10.1177/1754073915595098

Aziz-Zadeh, L., Kilroy, E., and Corcelli, G. (2018). Understanding Activation Patterns in Shared Circuits: Toward a Value Driven Model. Front. Hum. Neurosci. 12, 180. doi:10.3389/fnhum.2018.00180

Bara, F., and Gentaz, E. (2011). Haptics in Teaching Handwriting: The Role of Perceptual and Visuo-Motor Skills. Hum. Mov. Sci. 30 (4), 745-759. doi:10.1016/j.humov.2010.05.015

Bara, F., Gentaz, E., Colé, P., and Sprenger-Charolles, L. (2004). The Visuo-Haptic and Haptic Exploration of Letters Increases the Kindergarten-Children's Understanding of the Alphabetic Principle. Cogn. Dev. 19 (3), 433-449. hal00733557. doi:10.1016/j.cogdev.2004.05.003

Barrett, L. F., Gross, J., Christensen, T. C., and Benvenuto, M. (2001). Knowing What You're Feeling and Knowing What To Do About It: Mapping the Relation Between Emotion Differentiation and Emotion Regulation. Cogn. Emot. 15 (6), 713-724. doi:10.1080/02699930143000239

Barsalou, L. W. (1999). Perceptual Symbol Systems. Behav. Brain Sci. 22 (4), 577-609. doi:10.1017/S0140525X99002149

Barsalou, L. W. (2008). Grounded Cognition. Annu. Rev. Psychol. 59, 617-645. doi:10.1146/annurev.psych.59.103006.093639

Beach, P. T., Anderson, M. R. C., Jacovidis, J. N., and Chadwick, K. L. (2020) Making the Abstract Explicit: The Role of Metacognition in Teaching and Learning. Retrieved from: Available at: https://www.ibo.org/globalassets/ publications/ib-research/policy/metacognition-policy-paper.pdf.

Berkowicz, J., and Myers, A. (2018). Why Professional Development Fails. EdWeek, January 14, 2018. Retrieved from: Available at: https://www.edweek.org/teachinglearning/opinion-why-professional-development-fails/2018/01.

Bernstein, N. A. (1996). "On Dexterity and Its Development," in Dexterity and Its Development. Editors M. L. Latash and M. T. Turvey (Hillsdale, NJ: Lawrence Erlbaum Associates).

Berteletti, I., and Booth, J. R. (2015). Perceiving Fingers in Single-Digit Arithmetic Problems. Front. Psychol. 6, 226. doi:10.3389/fpsyg.2015.00226

Boaler, J. (2019). Limitless Mind: Learn, Lead, and Live without Barriers. Harper Collins.

Boaler, J., Chen, L., Williams, C. M., and Cordero, M. (2016). Seeing as Understanding: The Importance of Visual Mathematics for Our Brain 
and Learning. J. Appl. Comput. Maths. 5, 1-6. doi:10.4172/21689679.10003210.4172/2168-9679.1000325

Boaler, J., and Humphreys, C. (2005). Connecting Mathematical Ideas: Middle School Cases of Teaching \& Learning. New York, NY: Heinemann.

Boden, M. T., Thompson, R. J., Dizén, M., Berenbaum, H., and Baker, J. P. (2012). Are Emotional Clarity and Emotion Differentiation Related? Cogn. Emot. 27, 961-978. doi:10.1080/02699931.2012.751899

Butera, C., and Aziz-Zadeh, L. (2022). "Mirror Neurons and Social Implications for the Classroom," in Movement Matters: How Embodied Cognition Informs Teaching and Learning. Editors S. L. Macrine and J. M. B. Fugate (Cambridge, MA: MIT Press).

Cameron, C. D., Payne, B. K., and Doris, J. M. (2013). Morality in High Definition: Emotion Differentiation Calibrates the Influence of Incidental Disgust on Moral Judgments. J. Exp. Soc. Psychol. 49 (4), 719-725. doi:10.1016/j.jesp.2013.02.014

Caramazza, A., Anzellotti, S., Strnad, L., and Lingnau, A. (2014). Embodied Cognition and Mirror Neurons: A Critical Assessment. Annu. Rev. Neurosci. 37 (1), 1-15. doi:10.1146/annurev-neuro-071013-013950

Carbonneau, K. J., and Marley, S. C. (2015). Instructional Guidance and Realism of Manipulatives Influence Preschool Children's Mathematics Learning. J. Exp. Edu. 83 (4), 495-513. doi:10.1080/00220973.2014.989306

Carbonneau, K. J., Marley, S. C., and Selig, J. P. (2013). A Meta-Analysis of the Efficacy of Teaching Mathematics With Concrete Manipulatives. J. Educ. Psychol. 105 (2), 380-400. doi:10.1037/a0031084

Carsley, D., Khoury, B., and Heath, N. L. (2018). Effectiveness of Mindfulness Interventions for Mental Health in Schools: A Comprehensive Meta-Analysis. Mindfulness 9, 693-707. doi:10.1007/s12671-017-0839-2

Caspers, S., Zilles, K., Laird, A. R., and Eickhoff, S. B. (2010). ALE Meta-Analysis of Action Observation and Imitation in the Human Brain. NeuroImage 50 (3), 1148-1167. doi:10.1016/j.neuroimage.2009.12.112

Chelule, C. G., Woods, D., and Nathan, M. J. (2019). Collaborative Gesture as a Case of Extended Mathematical Cognition. J. Math. Behav. 55, 100683. doi:10.1016/j.jmathb.2018.12.002

Chemero, A. (2009). Radical Embodied Cognitive Science. Cambridge, MA: MIT Press. doi:10.1080/10888691.2018.1537791

Chen, R. S. Y., Ninh, A., Yu, B., and Abrahamson, D. (2020). "Being in Touch With the Core of Social Interaction: Embodied Design for the Nonverbal," in Proceedings of the 14th Annual Meeting of the International Society of the Learning Sciences, (ICLS 2020). Editors M. Gresalfi and I. S. Horn (Nashville: ISLS), 1681-1684.

Connor, C. M., Phillips, B. M., Kaschak, M., Apel, K., Kim, Y. S., Al Otaiba, S., Crowe, E. C., Thomas-Tate, S., Johnson, L. C., and Lonigan, C. J. (2014). Comprehension Tools for Teachers: Reading for Understanding From Prekindergarten Through Fourth Grade. Educ. Psychol. Rev. 26 (3), 379-401. doi:10.1007/s10648-014-9267-1

Darling-Hammond, L., Flook, L., Cook-Harvey, C., Barron, B., and Osher, D. (2020). Implications for Educational Practice of the Science of Learning and Development. Appl. Develop. Sci. 24 (2), 97-140. doi:10.1080/ 10888691.2018.1537791

De Jaegher, H. (2013). Embodiment and Sense-Making in Autism. Front. Integr. Neurosci. 7 (5), 15. doi:10.3389/fnint.2013.00015

Delgado, P., Vargas, C., Ackerman, R., and Salmerón, L. (2018). Don’t Throw Away Your Printed Books: A Meta-Analysis on the Effects of Reading Media on Reading Comprehension. Educ. Res. Rev. 25, 23-38. doi:10.1016/j.edurev.2018.09.003

Dewey, J. (1989). The Later Works. La Salle: SIU Press, 16, 1925-1953.

Donovan, A. M., and Alibali, M. W. (2021). Toys or Math Tools: Do Children's Views of Manipulatives Affect Their Learning? J. Cogn. Dev. 22 (2), 281-304. doi:10.1080/15248372.2021.1890602

Donovan, A. M., and Alibali, M. (2022). "Manipulatives and Mathematics Learning: The Role of Perceptual and Interactive Features," in Movement Matters: How Embodied Cognition Informs Teaching and Learning. Editors S. L. Macrine and J. M. B. Fugate (Cambridge, MA: MIT Press).

Donovan, A. M., Boncoddo, R., Williams, C. C., Walkington, C., Pier, E. L., and Alibali, M. W. (2014). "Action, Gesture and Abstraction in Mathematical Learning," in Thematic Panel Presented at the Sixth Conference of the International Society for Gesture Studies, San Diego, CA. July.

Dykstra Steinbrenner, J. R., and Watson, L. R. (2015). Student Engagement in the Classroom: The Impact of Classroom, Teacher, and Student
Factors. J. Autism Dev. Disord. 45 (8), 2392-2410. doi:10.1007/ s10803-015-2406-9

Eigsti, I.-M. (2013). A Review of Embodiment in Autism Spectrum Disorders. Front. Psychol. 4, 224. doi:10.3389/fpsyg.2013.00224

Eigsti, I. M., Rosset, D., Col Cozzari, G., da Fonseca, D., and Deruelle, C. (2015). Effects of Motor Action on Affective Preferences in Autism Spectrum Disorders: Different Influences of Embodiment. Dev. Sci. 18 (6), 1044-1053. doi:10.1111/Desc. 12278

Esopenko, C., Gould, L., Cummine, J., Sarty, G., Kuhlmann, N., and Borowsky, R. (2012). A Neuroanatomical Examination of Embodied Cognition: Semantic Generation to Action-Related Stimuli. Front. Hum. Neurosci. 6, 84. doi:10.3389/ fnhum.2012.00084

Every Child Succeeds Act (ESSA), Public Law No. 114-95, S.1177, 114th Cong. (2015). Retrieved from: Available at: https://www.congress.gov/114/plaws/ publ95/PLAW-114publ95.pdf.

Ferrari, P. F., and Coudé, G. (2018). "Mirror Neurons, Embodied Emotions, and Empathy," in Neuronal Correlates of Empathy: From Rodent to Human. Editors K. Z. Meyza and E. Knapska (London, United Kingdom: Elsevier Academic Press), 67-77. doi:10.1016/B978-0-12-805397-3.00006-1

Flanagan, J. R., and Johansson, R. S. (2003). Action Plans Used in Action Observation. Nature 424, 769-771. doi:10.1038/nature01861

Flavell, J. H. (1979). Metacognition and Cognitive Monitoring: A New Area of Cognitive-Developmental Inquiry. Am. Psychol. 34 (10), 906-911. doi:10.1037/ 0003-066X.34.10.906

Flood, V. J., (2018). Multimodal Revoicing as an Interactional Mechanism for Connecting Scientific and Everyday Concepts. Hum. Dev., 61 (3), 145-173. doi:10.1159/000488693

Flood, V. J., Shvarts, A., and Abrahamson, D. (2020). Teaching with Embodied Learning Technologies for Mathematics: Responsive Teaching for Embodied Learning. ZDM Maths. Edu. 52 (7), 1307-1331. doi:10.1007/s11858-02001165-7

Flood, V., Shvarts, A., and Abrahamson, D. (2022). "Responsive Teaching for Embodied Learning with Technology," in Movement Matters: How Embodied Cognition Informs Teaching and Learning. Editors S. L. Macrine and J. M. B. Fugate (Cambridge, MA: MIT Press).

Fugate, J. M. B., Macrine, S. L., and Cipriano, C. (2018). The Role of Embodied Cognition for Transforming Learning. Int. J. Sch. Educ. Psychol. 7 (4), 274-288. doi:10.1080/21683603.2018.1443856

Fugate, J. M. B., and Wilson-Mendenhall, C. (2022). "Embodied Emotion, Emotional Granularity, and Mindfulness: Improved Learning in the Classroom," in Movement Matters: How Embodied Cognition Informs Teaching and Learning. Editors S. L. Macrine and J. M. B. Fugate (Cambridge, MA: MIT Press).

Gallagher, S. (2005). Dynamic Models of Body Schematic Processes. Adv. Conscious. Res. 62, 233-250. doi:10.1075/aicr.62.15gal

Gallese, V. (2009). Mirror Neurons, Embodied Simulation, and the Neural Basis of Social Identification. Psychoanalytic Dialogues 19 (5), 519-536. doi:10.1080/ 10481880903231910

Gaver, W. W. (1991). "Technology Affordances," in Proceedings of the SIGCHI Conference on Human Factors in Computing Systems. Editors S. P. Robertson, G. M. Olson, and J. S. Olson (New York, NY: ACM Press), 79-84. doi:10.1145/108844.108856

Georgiou, Y., and Ioannou, A. (2019). Teachers' Concerns About Adopting Technology-Enhanced Embodied Learning and Their Mitigation through Professional Development. J. Tech. Teach. Edu. 27 (3), 335-371.

Gerofsky, S. (2011). "Chapter 18. Seeing the Graph vs. Being the Graph," in Integrating Gestures. Editors G. Stam and M. Ishino (Philadelphia, PA: John Benjamins), 245-256. doi:10.1075/gs.4.22ger

Gibson, J. J. (1979). The Ecological Approach to Visual Perception. Houghton Mifflin.

Giles, O. T., Shire, K. A., Hill, L. J. B., Mushtaq, F., Waterman, A., Holt, R. J., Williams, J. H. G., Wilkie, R. M., and Mon-Williams, M. (2018). Hitting the Target: Mathematical Attainment in Children Is Related to InterceptiveTiming Ability. Psychol. Sci. 29 (8), 1334-1345. doi:10.1177/ 0956797618772502

Gilliland, C. T., Sittampalam, G. S., Wang, P. Y., and Ryan, P. E. (2017). The Translational Science Training Program at NIH: Introducing Early Career Researchers to the Science and Operation of Translation of Basic Research to 
Medical Interventions. Biochem. Mol. Biol. Educ. 45 (1), 13-24. doi:10.1002/ bmb. 20978

Glenberg, A. M. (2008). "Toward the Integration of Bodily States, Language, and Action," in Embodied Grounding: Social, Cognitive, Affective, and Neuroscientific Approaches. Editors G. R. Semin and E. R. Smith (Cambridge, United Kingdom: Cambridge University Press), 43-70. doi:10.1017/CBO9780511805837.003

Glenberg, A. M. (2011). How Reading Comprehension Is Embodied and Why That Matters. Int. Electron. J. Elem. Edu. 4 (1), 5-18.

Glenberg, A. M., and Gallese, V. (2012). Action-Based Language: A Theory of Language Acquisition, Comprehension, and Production. Cortex 48 (7), 905-922. doi:10.1016/j.cortex.2011.04.010

Glenberg, A. M., and Kaschak, M. P. (2002). Grounding Language in Action. Psychon. Bull. Rev. 9 (3), 558-565. doi:10.3758/bf03196313

Glenberg, A. M., Becker, R., Klötzer, S., Kolanko, L., Müller, S., and Rinck, M. (2009). Episodic Affordances Contribute to Language Comprehension. Lang. Cogn. 1 (1), 113-135. doi:10.1515/langcog.2009.006

Glenberg, A. M., Goldberg, A. B., and Zhu, X. (2011). Improving Early Reading Comprehension Using Embodied CAI. Instr. Sci. 39, 27-39. doi:10.1007/ s11251-009-9096-7

Glenberg, A. M., Gutierrez, T., Levin, J. R., Japuntich, S., and Kaschak, M. P. (2004). Activity and Imagined Activity Can Enhance Young Children's Reading Comprehension. J. Educ. Psychol. 96, 424-436. doi:10.1037/00220663.96.3.424

Glenberg, A. M., Jaworski, B., Rischal, M., and Levin, J. (2007). "What Brains Are for: Action, Meaning, and Reading Comprehension," in Reading Comprehension Strategies: Theories, Interventions, and Technologies. Editor D. S. McNamara (Mahwah, NJ: Lawrence Erlbaum Associates Publishers), 221-240.

Gomez, L. E., and Glenberg, A. (2022). "Embodied Classroom Activities for Vocabulary Acquisition," in Movement Matters: How Embodied Cognition Informs Teaching and Learning. Editors S. L. Macrine and J. M. B. Fugate (Cambridge, MA: MIT Press).

Gracia-Bafalluy, M., and Noël, M. P. (2008). Does Finger Training Increase Young Children's Numerical Performance? Cortex 44 (4), 368-375. doi:10.1016/ j.cortex.2007.08.020

Gredebäck, G., and Falck-Ytter, T. (2015). Eye Movements During Action Observation. Perspect. Psychol. Sci. 10 (5), 591-598. doi:10.1177/ 1745691615589103

Grynszpan, O., Martin, J. C., and Fossati, P. (2017). Gaze Leading Is Associated With Liking. Acta Psychol. (Amst) 173, 66-72. doi:10.1016/j.actpsy.2016.12.006

Gulamhussein, A. (2013). Teaching the Teachers: Effective Professional Development in the Era of High Stakes Accountability. Columbus, $\mathrm{OH}$ : National School Board Association, Center for Public Education. Available at: http://conference.ohioschoolboards.org/2017/wp-\%20content/uploads/ sites/17/2016/07/1pm111317A114Job-embedPD.pdf.

Hall, R., and Nemirovsky, R. (2012). Introduction to the Special Issue: Modalities of Body Engagement in Mathematical Activity and Learning. J. Learn. Sci. 21 (2), 207-215. doi:10.1080/10508406.2011.611447

Harrison, L. A., Kats, A., Williams, M. E., and Aziz-Zadeh, L. (2019). The Importance of Sensory Processing in Mental Health: A Proposed Addition to the Research Domain Criteria (RDoC) and Suggestions for RDoC 2.0. Front. Psychol. 10, 103. doi:10.3389/fpsyg.2019.00103

Hashemiparast, M., Negarandeh, R., and Theofanidis, D. (2019). Exploring the Barriers of Utilizing Theoretical Knowledge in Clinical Settings: A Qualitative Study. Int. J. Nurs. Sci. 6, 399-405. doi:10.1016/j.ijnss.2019.09.008.

Hauk, O., Johnsrude, I., and Pulvermüller, F. (2004). Somatotopic Representation of Action Words in Human Motor and Premotor Cortex. Neuron. 41 (2), 301-307. doi:10.1016/S0896-6273(03)00838-9

Hill, C. L., and Updegraff, J. A. (2012). Mindfulness and Its Relationship to Emotional Regulation. Emotion 12 (1), 81-90. doi:10.1037/a0026355

Horvath, J. C., Donoghue, G. M., Horton, A. J., Lodge, J. M., and Hattie, J. A. C. (2018). On the Irrelevance of Neuromyths to Teacher Effectiveness: Comparing Neuro-Literacy Levels Amongst Award-Winning and Non-Award Winning Teachers. Front. Psychol. 9, 1666. doi:10.3389/fpsyg.2018.01666

Hostetter, A. B., and Alibali, M. W. (2019). Gesture as Simulated Action: Revisiting the Framework. Psychon. Bull. Rev. 26 (3), 721-752. doi:10.3758/s13423-018$1548-0$
Hutto, D. D. (2005). Knowing What? Radical Versus Conservative Enactivism. Phenom. Cogn. Sci. 4 (4), 389-405. doi:10.1007/978-1-4020-5558-4_710.1007/ s11097-005-9001-z

Hutto, D. D. (2007). "Folk Psychology Without Theory or Simulation," in Folk Psychology Re-Assessed. Editors D. D. Hutto and M. Ratcliffe (Dordrecht: Springer), 115-135.

Hutto, D. D., Kirchhoff, M. D., and Abrahamson, D. (2015). The Enactive Roots of STEM: Rethinking Educational Design in Mathematics. Educ. Psychol. Rev. 27 (3), 371-389. doi:10.1007/s10648-015-9326-2

Hutto, D. D., and Myin, E. (2012). Radicalizing Enactivism: Basic Minds Without Content. Cambridge, MA: MIT Press.

Hutto, D. D., and Myin, E. (2017). Evolving Enactivism: Basic Minds Meet Content. Cambridge, MA: MIT Press.

Iacoboni, M. (2009). Imitation, Empathy, and Mirror Neurons. Annu. Rev. Psychol. 60, 653-670. doi:10.1146/annurev.psych.60.110707.163604 PMID: 18793090

Iacoboni, M., Molnar-Szakacs, I., Gallese, V., Buccino, G., Mazziotta, J. C., and Rizzolatti, G. (2005). Grasping the Intentions of Others With One's Own Mirror Neuron System. Plos Biol. 3, e79. doi:10.1371/journal.pbio.0030079

Immordino-Yang, M. H., and Damasio, A. (2007). We Feel, Therefore We Learn: The Relevance of Affective and Social Neuroscience to Education. Mind, Brain Edu. 1 (1), 3-10.

Jagers, R. J., Rivas-Drake, D., and Williams, B. (2019). Transformative Social and Emotional Learning (SEL): Toward SEL in Service of Educational Equity and Excellence. Educ. Psychol. 54 (3), 162-184. doi:10.1080/ 00461520.2019 .1623032

James, K. H. (2010). Sensori-Motor Experience Leads to Changes in Visual Processing in the Developing Brain. Dev. Sci. 13 (2), 279-288. doi:10.1111/ j.1467-7687.2009.00883.x

James, K. H. (2017). The Importance of Handwriting Experience on the Development of the Literate Brain. Curr. Dir. Psychol. Sci. 26 (6), 502-508. doi:10.1177/0963721417709821

James, K. H. (2022). "The Embodiment of Letter Perception: The Importance of Handwriting in Early Childhood," in Movement Matters: How Embodied Cognition Informs Teaching and Learning. Editors S. L. Macrine and J. M. B. Fugate (Cambridge, MA: MIT Press).

James, K. H., and Engelhardt, L. (2012). The Effects of Handwriting Experience on Functional Brain Development in Pre-Literate Children. Trends Neurosci. Educ. 1 (1), 32-42. doi:10.1016/j.tine.2012.08.001

Johnson-Glenberg, M. C. (2018). Immersive VR and Education: Embodied Design Principles That Include Gesture and Hand Controls. Front. Robot. AI. doi:10.3389/frobt.2018.00081

Johnson-Glenberg, M. C. (2022). "Evaluating Embodied Immersive STEM VR Using the Quality of Education in Virtual Reality Rubric (QUIVRR)," in Movement Matters: How Embodied Cognition Informs Teaching and Learning. Editors S. L. Macrine and J. M. B. Fugate (Cambridge, MA: MIT Press).

Johnson-Glenberg, M. C., and Megowan-Romanowicz, C. (2017). Embodied Science and Mixed Reality: How Gesture and Motion Capture Affect Physics Education. Cogn. Res. Princ. Implic. 2 (24), s41235. doi:10.1186/ s41235-017-0060-9

Johnson-Glenberg, M. C., Megowan-Romanowicz, C., Birchfield, D. A., and SavioRamos, C. (2016). Effects of Embodied Learning and Digital Platform on the Retention of Physics Content: Centripetal Force. Front. Psychol. 7, 1819. 2016. Article. doi:10.3389/fpsyg.2016.018197

Kamii, C., Lewis, B. A., and Kirkland, L. (2001). Manipulatives: When Are They Useful?. J. Math. Behav. 20 (1), 21-31. doi:10.1016/S0732-3123(01)00059-1

Kaschak, M. P., Connor, C. M., and Dombek, J. L. (2017). Enacted Reading Comprehension: Using Bodily Movement to Aid the Comprehension of Abstract Text Content. PLoS One 12, e0169711. doi:10.1371/journal.pone.0169711

Kaschak, M. P., Madden, C. J., Therriault, D. J., Yaxley, R. H., Aveyard, M., Blanchard, A. A., and Zwaan, R. A. (2005). Perception of Motion Affects Language Processing. Cognition 94, B79-B89. doi:10.1016/j.cognition.2004.06.005

Kaslow, N. J. (2015). Translating Psychological Science to the Public. Am. Psychol. 70 (5), 361-371. doi:10.1037/a0039448

Kelton, M. L., and Ma, J. Y. (2018). Reconfiguring Mathematical Settings and Activity Through Multi-Party, Whole-Body Collaboration. Educ. Stud. Math. 98 (2), 177-196. doi:10.1007/s10649-018-9805-8 
Kelton, M. L., and Ma, J. Y. (2020). Assembling a Torus: Family Mobilities in an Immersive Mathematics Exhibition. Cogn. Instruction 38, 318-347. doi:10.1080/07370008.2020.1725013

Keysers, C., Paracampo, R., and Gazzola, V. (2018). What Neuromodulation and Lesion Studies Tell Us About the Function of the Mirror Neuron System and Embodied Cognition. Curr. Opin. Psychol. 24, 35-40. doi:10.1016/ j.copsyc.2018.04.001

Kiefer, M., Schuler, S., Mayer, C., Trumpp, N. M., Hille, K., and Sachse, S. (2015). Handwriting or Typewriting? The Influence of Pen- or Keyboard-Based Writing Training on Reading and Writing Performance in Preschool Children. Adv. Cogn. Psychol. 11, 136-146. doi:10.5709/acp-0178-7

Kilroy, E., Cermak, S. A., and Aziz-Zadeh, L. (2019). A Review of Functional and Structural Neurobiology of the Action Observation Network in Autism Spectrum Disorder and Developmental Coordination Disorder. Brain Sci. 9 (4), E75. doi:10.3390/brainsci9040075

Klein, C., Lester, J., Rangwala, H., and Johri, A. (2019). Technological Barriers and Incentives to Learning Analytics Adoption in Higher Education: Insights From Users. J. Comput. High Educ. 31 (3), 604-625. doi:10.1007/s12528-01909210-5

Kolb, D. A. (1984). Experiential Learning: Experience as the Source of Learning and Development. New Jersey: Prentice-Hall.

Kontra, C., Goldin-Meadow, S., and Beilock, S. L. (2012). Embodied Learning Across the Life Span. Top. Cogn. Sci. 4 (4), 731-739. doi:10.1111/j.1756-8765.2012.01221.x

Kontra, C., Lyons, D. J., Fischer, S. M., and Beilock, S. L. (2015). Physical Experience Enhances Science Learning. Psychol. Sci. 26 (6), 737-749. doi:10.1177/0956797615569355

Kosmas, P., and Zaphiris, P. (2018). Embodied Cognition and Its Implications in Education: An Overview of Recent Literature. World Acad. Sci. Eng. Tech. 12, 930-936. doi:10.1999/1307-6892/10009334

Kosmas, P., Ioannou, A., and Zaphiris, P. (2019). Implementing Embodied Learning in the Classroom: Effects on Children's Memory and Language Skills. Educ. Media Int. 56 (1), 59-74. doi:10.1080/ 09523987.2018.1547948

Krause, C. (2017). DeafMath: Exploring the Influence of Sign Language on Mathematical Conceptualization, 10. Dublin, Ireland: CERME.

Kumar, S., Tran, J., Moseson, H., Tai, C., Glenn, J. M., Madero, E. N., Krebs, C., Bott, N., and Juusola, J. L. (2018). The Impact of the Virtual Cognitive Health Program on the Cognition and Mental Health of Older Adults: Pre-Post 12Month Pilot Study. JMIR Aging 1 (2), e12031. doi:10.2196/12031

Ladda, A. M., Pfannmoeller, J. P., Kalisch, T., Roschka, S., Platz, T., Dinse, H. R., and Lotze, M. (2014). Effects of Combining 2 Weeks of Passive Sensory Stimulation With Active Hand Motor Training in Healthy Adults. PLoS ONE 9, e84402. doi:10.1371/journal.pone.0084402

Lakoff, G., and Johnson, M. (1980). Conceptual Metaphor in Everyday Language. J. Philos. 77 (8), 453-486. doi:10.2307/2025464

Lauer, J. E., and Lourenco, S. F. (2016). Spatial Processing in Infancy Predicts Both Spatial and Mathematical Aptitude in Childhood. Psychol. Sci. 27 (10), 1291-1298. doi:10.1177/0956797616655977

Lindgren, R., and Johnson-Glenberg, M. (2013). Emboldened by Embodiment. Educ. Res. 42 (8), 445-452. doi:10.3102/0013189X13511661

Lindgren, R., Tscholl, M., Wang, S., and Johnson, E. (2016). Enhancing Learning and Engagement through Embodied Interaction Within a Mixed Reality Simulation. Comput. Edu. 95, 174-187. doi:10.1016/j.compedu.2016.01.001

Longcamp, M., Anton, J. L., Roth, M., and Velay, J. L. (2003). Visual Presentation of Single Letters Activates a Premotor Area Involved in Writing. Neuroimage 19 (4), 1492-1500. doi:10.1016/S1053-8119(03)00088-0

Longcamp, M., Boucard, C., Gilhodes, J. C., Anton, J. L., Roth, M., Nazarian, B., and Velay, J. L. (2008). Learning Through Hand- or Typewriting Influences Visual Recognition of New Graphic Shapes: Behavioral and Functional Imaging Evidence. J. Cogn. Neurosci. 20 (5), 802-815. doi:10.1162/jocn.2008.20504

Longcamp, M., Zerbato-Poudou, M. T., and Velay, J. L. (2005). The Influence of Writing Practice on Letter Recognition in Preschool Children: A Comparison Between Handwriting and Typing. Acta Psychol. (Amst) 119 (1), 67-79. doi:10.1016/j.actpsy.2004.10.019

Ma, J. Y. (2017). Multi-Party, Whole-Body Interactions in Mathematical Activity. Cogn. Instruction 35 (2), 141-164. doi:10.1080/07370008.2017.1282485
Macrine, S. L. (2002). Pedagogical Bondage: Body Bound and Gagged in a Technorational World. Body Movements: Pedagogy, Polit. Soc. Change, 133-145.

Macrine, S. L., and Fugate, J. M. B. (2020). "Embodied Cognition," in Oxford Research Encyclopedia of Education (Oxford, United Kingdom: Oxford University Press), doi:10.1093/acrefore/9780190264093.013.885

Macrine, S. L., and Fugate, J. M. B. (2022). Movement Matters: How Embodied Cognition Informs Teaching and Learning. Cambridge, MA: MIT Press.

Mangen, A. (2008). Hypertext Fiction Reading: Haptics and Immersion. J. Res. Reading 31 (4), 404-419. doi:10.1111/j.1467-9817.2008.00380.x

Mangen, A., and Balsvik, L. (2016). Pen or Keyboard in Beginning Writing Instruction? Some Perspectives From Embodied Cognition. Trends Neurosci. Edu. 5 (3), 99-106. doi:10.1016/j.tine.2016.06.003

Mangen, A., and Velay, J.-L. (2010). "Digitizing Literacy: Reflections on the Haptics of Writing," in Advances in Haptics. Editor M. H. Zadeh, 385-402. IN-TECH web. doi:10.5772/8710

Mangen, A., Anda, L. G., Oxborough, G. H., and Brønnick, K. (2015). Handwriting Versus Keyboard Writing: Effect on Word Recall. J. Writing Res. 7 (2), 227-247. doi:10.17239/jowr-2015.07.02.1

Mangen, A., Olivier, G., and Velay, J. L. (2019). Comparing Comprehension of a Long Text Read in Print Book and on Kindle: Where in the Text and When in the Story? Front. Psychol. 10, 38. doi:10.3389/ fpsyg.2019.00038

Mangen, A., Walgermo, B. R., and Brønnick, K. (2013). Reading Linear Texts on Paper Versus Computer Screen: Effects on Reading Comprehension. Int. J. Educ. Res. 58, 61-68. doi:10.1016/j.ijer.2012.12.002

Marley, S. C., Levin, J. R., and Glenberg, A. M. (2007). Improving Native American Children's Listening Comprehension Through Concrete Representations. Contemp. Educ. Psychol. 32, 537-550. doi:10.1016/j.cedpsych.2007.03.003

Matsushita, R. (2017). The Paradox of Evidence-Based Education: From the Decline of Education to Abandonment of the Theories of Education. Esj 11, 101-119. doi:10.7571/esjkyoiku.11.101

Mayer, C., Wallner, S., Budde-Spengler, N., Braunert, S., Arndt, P. A., and Kiefer, M. (2020). Literacy Training of Kindergarten Children With Pencil, Keyboard or Tablet Stylus: The Influence of the Writing Tool on Reading and Writing Performance at the Letter and Word Level. Front. Psychol. 10, 3054. doi:10.3389/fpsyg.2019.03054

Mazzuca, C., and Borghi, A. M. (2019). "Chapter 2. Abstract Concepts and the Activation of Mouth-Hand Effectors," in Human Cognitive Processing 65: Perspectives on Abstract Concepts: Cognition Language and Communication. Editors M. Bolognesi and G. Steen (Amsterdam, Netherlands: John Benjamins), 43-57. doi:10.1075/hcp.65.03maz

McKenney, S. (2018). How Can the Learning Sciences (Better) Impact Policy and Practice?. J. Learn. Sci. 27 (1), 1-7. doi:10.1080/10508406.2017.1404404

Mechsner, F., Kerzel, D., Knoblich, G., and Prinz, W. (2001). Perceptual Basis of Bimanual Coordination. Nature 414 (6859), 69-73. doi:10.1038/ 35102060

Megowan-Romanowicz, C. (2022). "Physics and Gesture: Spatial Thinking and Mutual Manifestness," in Movement Matters: How Embodied Cognition Informs Teaching and Learning. Editors S. L. Macrine and J. M. B. Fugate (Cambridge, MA: MIT Press)

Merleau-Ponty, M. (1962). Phenomenology of Perception [Phénoménologie de la Perception]. New York: Humanities Press.

Montessori, M. M. (1969). The Four Planes of Development. AMI Commun. (2/3), 4-10.

Moyer, P. S. (2001). Are We Having Fun Yet? How Teachers Use Manipulatives to Teach Mathematics. Educ. Stud. Maths. 47 (2), 175-197. doi:10.1023/a: 1014596316942

Mueller, P. A., and Oppenheimer, D. M. (2014). The Pen Is Mightier Than the Keyboard: Advantages of Longhand Over Laptop Note Taking. Psychol. Sci. 25 (6), 1159-1168. doi:10.1177/0956797614524581

Naka, M. (1998). Repeated Writing Facilitates Children's Memory for Pseudocharacters and Foreign Letters. Mem. Cognit. 26 (4), 804-809. doi:10.3758/bf03211399

Nathan, M. J. (2012). Rethinking Formalisms in Formal Education. Educ. Psychol. 47 (2), 125-148. doi:10.1080/00461520.2012.667063 
Nathan, M. J., Schenck, K. E., Vinsonhaler, R., Michaelis, J. E., Swart, M. I., and Walkington, C. (2020). Embodied Geometric Reasoning: Dynamic Gestures During Intuition, Insight, and Proof. J. Educ. Psychol. 113, 929-948. doi:10.1037/edu0000638

Nathan, M. J., Walkington, C., Boncoddo, R., Pier, E., Williams, C. C., and Alibali, M. W. (2014). Actions Speak Louder With Words: the Roles of Action and Pedagogical Language for Grounding Mathematical Proof. Learn. Instruction 33, 182-193. doi:10.1016/j.learninstruc.2014.07.001

Nathan, M. J., Yeo, A., Boncoddo, R., Hostetter, A. B., and Alibali, M. W. (2019). Teachers' Attitudes About Gesture for Learning and Instruction. Gest. 18 (1), 31-56. doi:10.1075/gest.00032.nat

NCATS-NIH, (2020). National Center for Advancing Translational Sciences. Available at: https://ncats.nih.gov/

NIH (2020). Translational Science Spectrum. Available at: https://ncats.nih.gov/ translation/spectrum.

No Child Left Behind Act of 2001 (2002). P.L. U.S.C. 20, 107-110. \$ 6319.

Nutley, S., Walter, I., and Davies, H. T. O. (2009). Promoting Evidence-Based Practice. Res. Soc. Work Pract. 19 (5), 552-559. doi:10.1177/1049731509335496

O'Conner, R., De Feyter, J., Carr, A., Luo, J. L., and Romm, H. (2017). A Review of the Literature on Social and Emotional Learning for Students Ages 3-8: Characteristics of Effective Social and Emotional Learning Programs (Part 1 of 4). REL 2017-245. Regional Educational Laboratory Mid-Atlantic. Retrieved from: Available at: https://ies.ed.gov/ncee/edlabs/projects/project.asp?projectID=443.

Paige, D. D., Smith, G. S., and Magpuri-Lavell, T. (2019). Learning to Improve: Report of a Three-Year Capacity-Building Project Leveraging Professional Development + Coaching to Improve Third-Grade Reading Outcomes. Als 07, 193-223. doi:10.4236/als.2019.74013

Penner-Wilger, M., and Anderson, M. L. (2013). The Relation Between Finger Gnosis and Mathematical Ability: Why Redeployment of Neural Circuits Best Explains the Finding. Front. Psychol. 4, 877. doi:10.3389/fpsyg.2013.00877

Penner-Wilger, M., Fast, L., LeFevre, J., Smith-Chant, B. L., Skwarchuk, S., Kamawar, D., et al. (2009). "Subitizing, Finger Gnosis, and the Representation of Number," in Proceedings of the 31st Annual Cognitive Science Society (520-525). Editors N. Taatgen, H. V. Rijn, L. Schomaker, and J. Nerbonne (Austin, TX: Cognitive Science Society).

Petitmengin, C. (2007). Towards the Source of Thoughts. J. Conscious. Stud. 14 (3), $54-82$.

Piaget, J. (1952). The Origins of Intelligence in Children. New York, NY: W. W. Norton \& Co.

Piaget, J. (1968). Six Psychological Studies. D. Elkind (Trans.). New York: Random House.

Pulvermüller, F. (2005). Brain Mechanisms Linking Language and Action. Nat. Rev. Neurosci. 6 (7), 576-582. doi:10.1038/nrn1706 PMID: 15959465

Radford, L., and Roth, W. M. (2011). Intercorporeality and Ethical Commitment: An Activity Perspective on Classroom Interaction. Educ. Stud. Maths. 77 (2), 227-245. doi:10.1007/s10649-010-9282-1

Rasmussen, C., Stephan, M., and Allen, K. (2004). Classroom Mathematical Practices and Gesturing. J. Math. Behav. 23 (3), 301-323. doi:10.1016/ j.jmathb.2004.06.003

Rayner, K., Foorman, B. R., Perfetti, C. A., Pesetsky, D., and Seidenberg, M. S. (2001). How Psychological Science Informs the Teaching of Reading. Psychol. Sci. 2, 31-74. doi:10.1111/1529-1006.00004

Reinholz, D., Trninic, D., Howison, M., and Abrahamson, D. (2010). "It's Not Easy Being Green: Embodied Artifacts and the Guided Emergence of Mathematical Meaning," in Proceedings of the Thirty-Second Annual Meeting of the North-American Chapter of the International Group for the Psychology of Mathematics Education (PME-NA 32). Editors P. Brosnan, D. Erchick, and L. Flevares (Columbus, OH: PME-NA), 1488-1496.

Rizzolatti, G., Fadiga, L., Gallese, V., and Fogassi, L. (1996). Premotor Cortex and the Recognition of Motor Actions. Brain Res. Cogn. Brain Res. 3 (2), 131-141. doi:10.1016/0926-6410(95)00038-0

Robertson, A. D., Scherr, R. E., and Hammer, D. (2016). Responsive Teaching in Science and Mathematics. New York: Routledge.

Roediger, H. L. (2013). Applying Cognitive Psychology to Education: Translational Educational Science. Psychol. Sci. Public Interest 14, 1-3. doi:10.1177/ 1529100612454415
Roemer, L., Williston, S. K., and Rollins, L. G. (2015). Mindfulness and Emotion Regulation. Curr. Opin. Psychol. 3, 52-57. doi:10.1016/ j.copsyc.2015.02.006

Rogoff, B. (1990). Apprenticeship in Thinking: Cognitive Development in Social Contexts. Oxford, United Kingdom: Oxford University Press.

Roschelle, J., Bakia, M., Toyama, Y., and Patton, C. (2011). Eight Issues for Learning Scientists About Education and the Economy. J. Learn. Sci. 20 (1), 3-49. doi:10.1080/10508406.2011.528318

Rosenbaum, L. F., Kaur, J., and Abrahamson, D. (2020). Shaping Perception: Designing for Participatory Facilitation of Collaborative Geometry. Digit Exp. Math. Educ. 6, 191-212. doi:10.1007/s40751-020-00068-2

Rowlands, M. (2010). The New Science of the Mind. Cambridge, MA: MIT Press. doi:10.7551/mitpress/9780262014557.001.0001

Rubio, D. M., Schoenbaum, E. E., Lee, L. S., Schteingart, D. E., Marantz, P. R., Anderson, K. E., Platt, L. D., Baez, A., and Esposito, K. (2010). Defining Translational Research: Implications for Training. Acad. Med. 85 (3), 470-475. 2010 Mar. doi:10.1097/ACM.0b013e3181ccd618

Saarni, C. (1997). Coping With Aversive Feelings. Motiv. Emot. 21 (1), 45-63. doi:10.1023/A:1024474314409

Schenck, K. E., Walkington, C., and Nathan, M. J. (2022). "Groups That Move Together, Prove Together: Collaborative Gestures and Gesture Attitudes Among Teachers Performing Embodied Geometry," in Movement Matters: How Embodied Cognition Informs Teaching and Learning. Editors S. L. Macrine and J. M. B. Fugate (Cambridge, MA: MIT Press).

Shvarts, A., and Abrahamson, D. (2019). Dual-Eye-Tracking Vygotsky: A Microgenetic Account of a Teaching/Learning Collaboration in an Embodied-Interaction Technological Tutorial for Mathematics. Learn. Cult. Soc. Interaction 22, 100316. doi:10.1016/j.lcsi.2019.05.003

Smyrnaiou, Z., and Sotiriou, M. (2016). D2.3 Effective Learning Environments for Inquiry Learning and Teaching. Los Angeles, CA: EU Project CREATIONS. CREATIONS (2015-2018), H2020-SEAC-2014-1CSA, 665917.

Suwa, M. (2006). A Cognitive Model of Acquiring Embodied Expertise Through Meta-Cognitive Verbalization. Trans. Jpn. Soc. Artif. Intelligence 23 (3), 141-150.

Tan, Y. S. M., and Amiel, J. J. (2019). Teachers Learning to Apply Neuroscience to Classroom Instruction: Case of Professional Development in British Columbia. Prof. Dev. Edu., 1-18. doi:10.1080/19415257.2019.1689522

Tancredi, S., Chen, R. S. Y., Krause, C., and Siu, Y-T. (2022). "The Need for SPEED: Reimagining Accessibility Through Special Education Embodied Design," in Movement Matters: How Embodied Cognition Informs Teaching and Learning. Editors S. L. Macrine and J. M. B. Fugate (Cambridge, MA: MIT Press).

Tanner, K. D. (2012). Promoting Student Metacognition. CBE Life Sci. Educ. 11 (2), 113-120. doi:10.1187/cbe.12-03-0033

Thompson, E. (2007). Mind in Life. Cambridge, MA: Harvard University Press.

Trninic, D., and Abrahamson, D. (2012). "Embodied Artifacts and Conceptual Performances," in Proceedings of the International Conference of the Learning Sciences: Future of Learning (ICLS 2012), Sydney, Australia. Editors J. V. Aalst, K. Thompson, M. J. Jacobson, and P. Reimann (Sydney: University of Sydney/ ISLS), Vol. 1, 283-290.

Tugade, M. M., Fredrickson, B. L., and Barrett, L. F. (2004). Psychological Resilience and Positive Emotional Granularity: Examining the Benefits of Positive Emotions on Coping and Health. J. Pers. 72 (6), 1161-1190. doi:10.1111/j.1467-6494.2004.00294.x

Varela, F. J., Thompson, E., and Rosch, E. (1991). The Embodied Mind: Cognitive Science and Human Experience. Cambridge, MA: MIT Press.

Vieyra, R. (2018). "Teaching Students Metacognition Through Discipline-Based Research and Technology," in Einstein Fellows: Best Practices in STEM Education. 2nd Ed. (New York: Peter Lang Inc).

Vierya, R., and Vierya, C. (2022). "Immersive Learning Experiences in Augmented Reality (AR): Visualizing and Interacting With Magnetic Fields," in Movement Matters: How Embodied Cognition Informs Teaching and Learning. Editors S. L. Macrine and J. M. B. Fugate (Cambridge, MA: MIT Press). 
Vieyra, R., Vieyra, C., Pendrill, A.-M., and Xu, B. (2020). Gamified Physics Challenges for Teachers and the Public. Phys. Educ. 55, 045014. doi:10.1088/1361-6552/ab8779

Vinci-Booher, S., and James, K. H. (2020). Visual Experiences During Letter Production Contribute to the Development of the Neural Systems Supporting Letter Perception. Dev. Sci. 23 (5), e12965.

Vogelstein, L., Brady, C., and Hall, R. (2019). Reenacting Mathematical Concepts Found in Large-Scale Dance Performance Can Provide Both Material and Method for Ensemble Learning. ZDM Maths. Edu. 51 (2), 331-346. doi:10.1007/s11858-019-01030-2

Vygotsky, L. S. (1926/1997). Educational Psychology (R. H. Silverman, Trans.). Boca Raton: CRC Press LLC. Original Work Published 1926.

Vygotsky, L. S. (1978). Mind in Society: The Development of Higher Psychological Processes. Editors M. Cole, V. John-Steiner, S. Scribner, and E. Souberman. (Cambridge, MA: Harvard University Press).

Walkington, C., Chelule, G., Woods, D., and Nathan, M. J. (2019). Collaborative Gesture as a Case of Extended Mathematical Cognition. J. Math. Behav. 55, 100683. doi:10.1016/j.jmathb.2018.12.002

Weinstein, Y., Madan, C. R., and Sumeracki, M. A. (2018). Teaching the Science of Learning. Cogn. Res. Princ. Implic. 3 (2), 2. doi:10.1186/s41235-0170087-y

Weisberg, S. M., and Newcombe, N. S. (2017). How Do (Some) People Make a Cognitive Map? Routes, Places, and Working Memory. J. Exp. Psychol. Learn. Mem. Cogn. 42 (5), 768-785. doi:10.1037/xlm0000200

Wertsch, J. V. (1985). Vygotsky and the Social Formation of Mind. Cambridge, MA: Harvard University Press.

Wilcox, G., Morett, L. M., Hawes, Z., and Dommett, E. J. (2020). Why Educational Neuroscience Needs Educational and School Psychology to
Effectively Translate Neuroscience to Educational Practice. Front. Psychol. 11, 618449. doi:10.3389/fpsyg.2020.618449

Willingham, D. T. (2009). Three Problems in the Marriage of Neuroscience and Education. Cortex 45 (4), 544-545. doi:10.1016/j.cortex.2008.05.009

Wilson, A., and Foglia, L. (2011). Embodied Cognition. Stanford Encyclopedia of Philosophy. Available at: https://philpapers.org/rec/WILEC.

Wilson, M. (2002). Six Views of Embodied Cognition. Psychon. Bull. Rev. 9 (4), 625-636. doi:10.3758/BF03196322

Zwaan, R. A. (2014). Embodiment and Language Comprehension: Reframing the Discussion. Trends Cogn. Sci. 18 (5), 229-234. doi:10.1016/ j.tics.2014.02.008

Conflict of Interest: The authors declare that the research was conducted in the absence of any commercial or financial relationships that could be construed as a potential conflict of interest.

Publisher's Note: All claims expressed in this article are solely those of the authors and do not necessarily represent those of their affiliated organizations, or those of the publisher, the editors and the reviewers. Any product that may be evaluated in this article, or claim that may be made by its manufacturer, is not guaranteed or endorsed by the publisher.

Copyright (๑) 2021 Macrine and Fugate. This is an open-access article distributed under the terms of the Creative Commons Attribution License (CC BY). The use, distribution or reproduction in other forums is permitted, provided the original author(s) and the copyright owner(s) are credited and that the original publication in this journal is cited, in accordance with accepted academic practice. No use, distribution or reproduction is permitted which does not comply with these terms. 